\title{
A Tangible Game-Based Approach for Introducing Programming to Elementary School Students
}

\author{
Rashidah Mokhtar, Mohd Lezam Lehat, Nora Mohd Basir, and Yusnita Sokman
}

\begin{abstract}
Critical thinking should be taught as early as childhood stage. The skill is very important meant for developing creative and innovative minds. Hence, it can be introduced through programming substance. However, there is a lack of study on introducing programming substance at the elementary school level especially using tangible game approach. Thus, this study is to determine students' tendency toward tangible game-based approach in introducing learning programming. A survey has been distributed to forty-nine elementary school students aged 11 to 12 years old. The students need to play a tangible game-based on critical thinking namely "Beat the clock - Sorting Networks". The result shows that students tend to enjoy a tangible outdoor game play with friends and it is help in developing their problem solving skills. Therefore, we suggest to design a tangible game-based that suitable with the elementary school students deliberate for emerging and sharpening their critical thinking skills.
\end{abstract}

Index Terms-Tangible game-based, introductory programming, elementary school.

\section{INTRODUCTION}

The increasing popularity of game-based has been a motivational tool and an innovative approach in introducing programming course in diverse ways. The issues on its benefits and effect have been discussed by a lot of researchers [1]-[3] since the 1960s [4]. Game-based approach is divided into three types: digital game-based, tangible game-based and hybrid game-based. Digital game is involving computer usage while the hybrid game is a combination of digital and tangible elements. Some researchers [5], [6] define tangible as a physical interaction mediators to the computer functions. It is almost similar to the concept of hybrid. On the contrary, in this paper we define tangible game-based as an augment the physical elements and real environment without computer use. There are a lot of interesting and useful, tangible game-based produced by researchers such as Tangicons, Robo-Blocks, Tern, T_ProRob, Quetzal and Tangible Programming Brick. These games boost critical thinking, problem solving and

Manuscript received March 8, 2014; revised May 9, 2014. This work was supported in part by the Universiti Teknologi MARA Johor under Execellence Grant. The title of the paper is "A Tangible Game - Based Approach for Introducing Programming to Elementary School Students".

Rashidah Mokhtar, Mohd Lezam Lehat, and Yusnita Sokman are with the Department of Computer Science, Faculty of Computer and Mathematical Sciences, Universiti Teknologi MARA Johor, CO. 85009 Malaysia (e-mail: rashi271@johor.uitm.edu.my, yusni996@johor.uitm.edu.my).

Nora Mohd Basir is with the Department of Statistic, Faculty of Computer and Mathematical Sciences, Universiti Teknologi MARA Johor, CO. 85009 Malaysia (e-mail: noram661@johor.uitm.edu.my). creative thinking skill. These skills are very important in education to produce students who highly innovative and creative thus it is in line with the Malaysian Vision 2020. Therefore, we believe that introduce a programming, substance in early age will help in producing a very good generation in the future. However the challenge taken into place where the issue on how to introduce programming course to the children need to be highlighted. What are the suitable mechanisms should be adopted to make sure programming course easy to understand and fun. In the first place, why programming course is so important? As we have mentioned before, programming is one of the course that teach critical thinking and problem solving skill, which is very essential in their real life. In this research, we adopt tangible game-based approach to introduce programming to children because the game is one of the best approaches that can influence children to learn fast. We strongly believe that it will create fun and exciting during learning programming. Another motivation to pursue this research is because there is limited research centering on the tangible game-based in this context. Thus, objective of this paper is to determine the students' tendency of tangible game-based on introducing programming at the elementary school level. The next section, discuss more detail on tangible game-based and the advantages, methodology used, result and findings, future work and conclusion.

\section{TANGIBLE GAME-BASED}

Ever since early childhood, there are so many types of games either tangible or physical game like a ball, letters, cube, Lego and block or digital game (whether use computer or built-in computer system in the game) has been exposed. These games are created according to level of age. There are a lot of creative games created to attract children, develop their cognitive, social and physical [7]. It shows that the game is one of successful techniques that can stimulate human mind. The game also has fun elements that can attract children who easily get bored and it also can develop children experience constructively. Game trend nowadays is more in the direction of digital game or a game using android operating system. There are so many games can be downloaded free through Play Store for android user. From our experience and observation, game has its own education value according to the type of game and level of the game. Looking at the enormous influence of game among people nowadays, we are enthusiastic to expose tangible game approach to children for introducing programming course.

Why tangible or physical game-based? According to Scharf [8], tangible game will reduce cognitive disconnect between the task and the game goal because children can 
work directly with physical programming elements. Thus, children can learn directly to the game itself and have their own experience. While Verhaegh [3] also agree that tangible interface is easier to understand and use compared to the virtual interface. Thus, learning programs through physical material give good logic and make children more understand while they are relating the game task to real environment. This type of game also is suitable for young children and children with disabilities. Beside problem solving skill, there are other skills children can gain from the game such as interaction, collaboration, exploration, risk taking and decision making. There are many tangible game have been created by experts. Table I shows an example of tangible games for children, according to level, approach and category of game.

TABLE I: EXAMPLE OF TANGIBLE GAME-BASED FOR CHILDREN

\begin{tabular}{l|l|l|l}
\hline \hline Game & Level & Approach & Category \\
\hline $\begin{array}{l}\text { Tangicons [8] } \\
\text { first grade students }\end{array}$ & $\begin{array}{l}\text { Individual / } \\
\text { group }\end{array}$ & Cube \\
\hline $\begin{array}{l}\text { Criticality - board } \\
\text { game [9] }\end{array}$ & University & Individual & Board \\
\hline $\begin{array}{l}\text { Computer Science } \\
\text { through games and } \\
\text { puzzle [10] }\end{array}$ & Elementary & $\begin{array}{l}\text { Group / } \\
\text { individual }\end{array}$ & $\begin{array}{l}\text { Puzzle, } \\
\text { board }\end{array}$ \\
\hline $\begin{array}{l}\text { Hunting the Snark } \\
\text { [11] }\end{array}$ & $7-9$ & Group & $\begin{array}{l}\text { Puzzle, } \\
\text { board }\end{array}$ \\
\hline Read-it [12] & 5-7 years old & Group & Board \\
\hline $\begin{array}{l}\text { Tern [13] } \\
\text { late elementary } \\
\text { school students }\end{array}$ & $\begin{array}{l}\text { Individual / } \\
\text { group }\end{array}$ & $\begin{array}{l}\text { Block and } \\
\text { Jigsaw } \\
\text { puzzle }\end{array}$ \\
\hline $\begin{array}{l}\text { Robo-Blocks [14] } \\
\text { [16] }\end{array}$ & $8-9$ years & $\begin{array}{l}\text { Individual / } \\
\text { group }\end{array}$ & Maze \\
\hline \hline Curlybot [15] & $>4$ years & Individual & Board \\
\hline Tangible & Children lower age & $\begin{array}{l}\text { Individual / } \\
\text { group }\end{array}$ & Card \\
\hline
\end{tabular}

\section{Methodology}

The study was conducted during the weekend (Saturday) at Sekolah Kebangsaan Jementah Segamat, Johor. The school is located approximately $25 \mathrm{~km}$ from Segamat city. This school is categorized as a rural school. In order to investigate students' tendency in learning programming through tangible game-based approach, we have designed two different surveys given before and after tangible game conducted. This is not pre-test and post-test method. Before we conducted tangible game-based, there is a briefing session given by a researcher for this event. After that, students need to fill in the first survey that consists of twelve questions. The first survey is to get students' background. Then, the students have been asked to perform a group of 10 members that divide them into five groups. We use the tangible game, namely "Beat the clock - Sorting Networks" as in Fig 1. This game is taken from Computer Science Unplugged Activities through games and puzzle [10]. Before beginning, students need to follow instruction given. Then, they are given a set of 6 numbers unsorted, means that only six students require accomplishing this game. In a group, they should sort the numbers in ascending order based on the instructions given. Each group is given only 10 minutes to sort the numbers with only three attempts to finish the game. After that, each student who plays the game need to answer a survey that consists of twelve questions which embed five Likert Scales (strongly agree - agree - not sure - not agree - strongly disagree). The questions are adapted from Ibrahim [17].

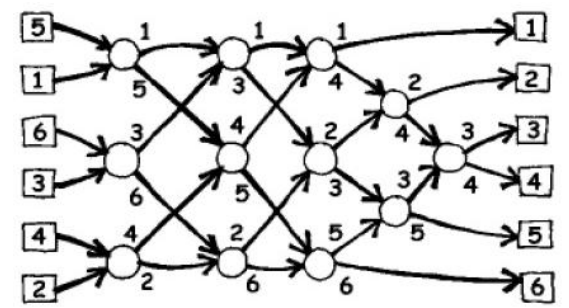

Fig. 1. Example of beat the clock - sorting networks game.

\section{RESUltS AND FINDINGS}

In this section discuss the analysis of findings and results derived from the research. The first analysis done is to overview the demography and information technology (IT) background of the participants' as in Table II. There are forty-nine students age 11 and 12 years participate in this study. It is approximately (90\%) of overall upper elementary school students at the school. From that, $(69.4 \%)$ of them are male and the rest are female. From the 49 participants, $(73.5 \%)$ of the them have personal computer. The computer has been used mostly to find information from the internet $(48.2 \%)$. Beside that, computers are used to play games $(37.6 \%)$, to do homework $(14.1 \%)$, and other purposes $(3.5 \%)$. The occurrence of play is more than once a day, which contributes $(31 \%)$. Time used in every session mostly less than 30 minutes and more than one hour has the same frequency $(36.4 \%)$. The usage is seemed contradict maybe because their parents control their play time even they have their own computer. About (32.9\%) of participants play games because of hobby and $(27.6 \%)$ to fill their leisure time. It is significantly shown that children like to play games during their free time. This is a great opportunity to design a game for academic purpose which combines education and entertainment.

TABLE II: TABULATION OF OVERALL PARTICIPANTS' IT BACKGROUND

\begin{tabular}{|c|c|c|}
\hline IT Background & Frequency & $\%$ \\
\hline \multicolumn{3}{|l|}{ Personal Computer } \\
\hline Yes & 36 & 73.5 \\
\hline No & 13 & 26.5 \\
\hline \multicolumn{3}{|l|}{ Usage } \\
\hline Do homework & 12 & 14.1 \\
\hline Find information from internet & 41 & 48.2 \\
\hline Playing games & 32 & 37.6 \\
\hline Others & 3 & 3.5 \\
\hline \multicolumn{3}{|l|}{ Time used in every session } \\
\hline Less than 30 minutes & 16 & 36.4 \\
\hline $30-59$ minutes & 12 & 27.2 \\
\hline More than 1 hour & 16 & 36.4 \\
\hline \multicolumn{3}{|l|}{ Play for } \\
\hline Learn / explore & 20 & 26.3 \\
\hline Hobby & 25 & 32.9 \\
\hline Leisure time & 21 & 27.6 \\
\hline Academic & 10 & 13.2 \\
\hline
\end{tabular}


We also have found that most of the participants preferred outdoor games, subsequently board game, block game, traditional game and others with percentage $(58 \%, 26 \%, 9 \%$, $5 \%$ and $2 \%$ ) respectively. It shows clearly in Fig. 2, that students' tendency toward tangible game is more of the outdoor activities. It's supported by $83.7 \%$ of the participants like to play a tangible game in a group or with friends compare to individual (16.3\%).

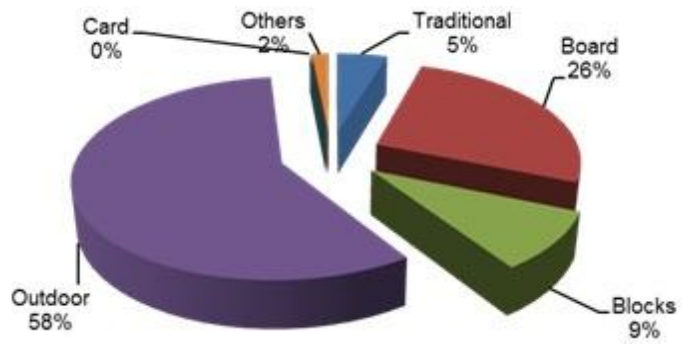

Fig. 2. Pie chart shows types of tangible games.

The next analysis of the findings is to excavate more detail on the participants' tendency of the game. There are twelve questions have been asked in the survey to measure the tendency. Reliability test has been done with these items. In general, reliabilities less than 0.6 are considered to be poor, those in the 0.70 range, acceptable, and those over 0.80 good From the test, Cronbach's Alpha value is 0.902, which is more than 0.8 . Thus, the internal consistency reliability of the measures used in this study can be considered to be good to measure the participants' tendency towards the tangible game-based which has significantly impacted in introducing fundamental of programming and develop critically and problem solving skills to elementary school students. Table III explains the participants' level of tendency toward tangible game-based.

Overall, all the participants 'strongly agree' and 'agree' that this tangible game is fun. It shows that participants really enjoy the game and its benefits them. It is supported by $94 \%$ agree, this game helps them in their study. Furthermore, 40 participants who contribute $81.6 \%$ find this game help them learn better learning by them self. $85.7 \%$ of the participants also agree that the games give them the opportunity to choose their learning style, even though $6 \%$ of them do not agree with the statement. It shows that, games can be one of the alternative tools in teaching and learning, however choosing the right game for the specific user is an important aspect in determining the efficacy of the game. As the cognitive development, this tangible game-based is perceived helping them in critical thinking, make them excited to solve the problem given and challenge their understanding with all of the 43 participants $(87.8 \%)$ give the same percentage of agreement for those statements. From this analysis, we can say that tangible game really inspires them in developing their logical thinking level in the way to expose them to the programming language.

Discussing on the game interface, 41 of the participants agree that the content of the game is fun, but there is about $10 \%$ find really difficult to play the game. Surprisingly, about $90 \%$ of the participants need only a short time to understand the game and $87.8 \%$ like to play this tangible game based. However, there is still some of the participant need more time in understanding the game and do not like this game, $6.1 \%$ and $8.2 \%$ respectively. It is a good feedback for researchers to look at when designing a tangible game in the forthcoming. The instructions must be straightforward and the elements of tangible game must be interesting enough for targeted user. From the student expectation, we can see that more than almost $90 \%$ is interested in using games for learning and $83.6 \%$ are really agreeing that they learn a lot from the game. However, there is quite a big percentage $(12.3 \%)$ of disagree on the learning input from the game for the participant that must be considered in developing the right games to help them in learning a programming language.

TABLE III: PARTICIPANTS' LEVEL OF TENDENCY TOWARDS TANGIBLE

\begin{tabular}{|c|c|c|c|c|c|c|c|}
\hline \multicolumn{8}{|c|}{ GAME-BASED } \\
\hline \multicolumn{2}{|l|}{ Statement } & SD & $\mathrm{D}$ & NS & A & SA & Total \\
\hline \multirow{2}{*}{$\begin{array}{l}\text { I think this game is } \\
\text { fun }\end{array}$} & $\mathrm{n}$ & 0 & 0 & 0 & 14 & 35 & 49 \\
\hline & $\%$ & 0.0 & 0.0 & 0.0 & 28.6 & 71.4 & 100 \\
\hline \multirow{2}{*}{$\begin{array}{l}\text { I think this game } \\
\text { helps in my study }\end{array}$} & $\mathrm{n}$ & 0 & 0 & 3 & 22 & 24 & 49 \\
\hline & $\%$ & 0.0 & 0.0 & 6.1 & 44.9 & 49.0 & 100 \\
\hline \multirow{2}{*}{$\begin{array}{l}\text { I think I can learn } \\
\text { better by myself }\end{array}$} & $\mathrm{n}$ & 1 & 1 & 7 & 15 & 25 & 49 \\
\hline & $\%$ & 2.0 & 2.0 & 14.3 & 30.6 & 51.0 & 100 \\
\hline \multirow{2}{*}{$\begin{array}{l}\text { I prefer to choose } \\
\text { my learning style }\end{array}$} & $\mathrm{n}$ & 3 & 0 & 4 & 18 & 24 & 49 \\
\hline & $\%$ & 6.1 & 0.0 & 8.2 & 36.7 & 49.0 & 100 \\
\hline \multirow{2}{*}{$\begin{array}{l}\text { The game helps in } \\
\text { critical thinking }\end{array}$} & $\mathrm{n}$ & 0 & 0 & 6 & 16 & 27 & 49 \\
\hline & $\%$ & 0.0 & 0.0 & 12.2 & 32.7 & 55.1 & 100 \\
\hline \multirow{2}{*}{$\begin{array}{l}\text { I am excited to } \\
\text { solve the problem } \\
\text { given }\end{array}$} & $\mathrm{n}$ & 0 & 2 & 4 & 15 & 28 & 49 \\
\hline & $\%$ & 0.0 & 4.1 & 8.2 & 30.6 & 57.1 & 100 \\
\hline \multirow{2}{*}{$\begin{array}{l}\text { The game } \\
\text { challenges my } \\
\text { understanding }\end{array}$} & $\mathrm{n}$ & 2 & 1 & 3 & 13 & 30 & 49 \\
\hline & $\%$ & 4.1 & 2.0 & 6.1 & 26.5 & 61.2 & 100 \\
\hline \multirow{2}{*}{$\begin{array}{l}\text { The content of the } \\
\text { game is fun }\end{array}$} & $\mathrm{n}$ & 4 & 1 & 3 & 12 & 29 & 49 \\
\hline & $\%$ & 8.2 & 2.0 & 6.1 & 24.5 & 59.2 & 100 \\
\hline \multirow{2}{*}{$\begin{array}{l}\text { I need a short time } \\
\text { to understand how } \\
\text { to play the game }\end{array}$} & $\mathrm{n}$ & 2 & 1 & 2 & 15 & 29 & 49 \\
\hline & $\%$ & 4.1 & 2.0 & 4.1 & 30.6 & 59.2 & 100 \\
\hline \multirow{2}{*}{$\begin{array}{l}\text { I like to play this } \\
\text { game }\end{array}$} & $\mathrm{n}$ & 3 & 1 & 2 & 16 & 27 & 49 \\
\hline & $\%$ & 6.1 & 2.0 & 4.1 & 32.7 & 55.1 & 100 \\
\hline \multirow{2}{*}{$\begin{array}{l}\text { I am interested in } \\
\text { using games for } \\
\text { learning }\end{array}$} & $\mathrm{n}$ & 0 & 2 & 3 & 15 & 29 & 49 \\
\hline & $\%$ & 0.0 & 4.1 & 6.1 & 30.6 & 59.2 & 100 \\
\hline \multirow{2}{*}{$\begin{array}{l}\text { I learn a lot from } \\
\text { this game }\end{array}$} & $\mathrm{n}$ & 2 & 4 & 2 & 18 & 23 & 49 \\
\hline & $\%$ & 4.1 & 8.2 & 4.1 & 36.7 & 46.9 & 100 \\
\hline
\end{tabular}

SD - Strongly Disagree; D - Disagree; NS Not Sure; A - Agree; SA Strongly Agree

The discussion shows, the students' tendency toward tangible game is because the easiness and interesting interface of the game will influence students' motivation in developing cognitive skill. They also can challenge their problem solving skill in the game. Thus, the learning process can be done in relax and fun way.

\section{FUTURE WORK}

Looking at the influence and the positive effect of game-based learning, we are enthusiastic to propose a design of tangible game-based using the board in introducing programming to elementary school students. The design of the game must consist of a very simple and clear instruction, have fun and interesting interface and the content must suitable with level of students. The game will be tested and implemented in the elementary school level. It will be a fundamental subject of problem solving, critical thinking and cognitive development from the elementary school level. 


\section{CONCLUSION}

In this paper, we discuss on the tendency of tangible game-based among elementary school students. For that, we use tangible game 'Beat the clock - Sorting Networks' that teach the algorithm on how to sort numbers in ascending order. The uniqueness of this research is we are using outdoor game, differing from other researchers mostly uses indoor tangible-game approach. The result's proposition of our study consists in designing a new tangible game-based that suitable to elementary school level. The details of our results will give full insights for developers, curriculum maker and teachers in considering tangible game-based approach in teaching and learning. Developers will get information regarding the possible factors in improving the design of tangible game-based. While for curriculum maker and teacher can use this finding as a guideline in introducing programming to children. The results of finding prove, tangible game can be a creative approach in introducing programming to elementary school students. It is also shown students' tendency toward the game because of easiness and attractive interface of the game.

\section{ACKNOWLEDGMENT}

This research was funded by the Excellence Grant, Universiti Teknologi MARA (reference number: (600-UiTMCJ (PJIA.5/2)) from Jun 2012 until July 2013.

\section{REFERENCES}

[1] H.-C. Hsu, S. N. Iyer, and A. Fogel, "Effects of social games on infant vocalizations," Journal of Child Language, pp. 1-23, 2013.

[2] M.-C. Li and C.-C. Tsai, "Game-based learning in science education: a review of relevant research," Journal of Science Education and Technology, vol. 20, pp. 87-898, 2013.

[3] J. Verhaegh, W. Fontijin, and A. Jacobs, "On the benefits of tangible interface for educational games," in Proc. the 2nd IEEE International Conference on Digital Game and Intelligent Toy Enhanced Learning. IEEE, 2008, pp. 41-145.

[4] T. Sapounidis and S. Demetriadis, "Tangible versus graphical user interfaces for robot programming: exploring cross-age children's preferences," Journal of Personal Ubiquitous Computing, pp. 1775-1786, 2013.

[5] I. Bezáková and J. E. Heliotis. "Board game strategies in introductory computer science," in Proc. the 44th ACM Technical Symposium on Computer Science Education, New York, 2013.

[6] J. G. Mohebzada and A. H. Bhojani, "The cubes: a tangible game-based learning system," in Proc. The International Conference on Innovations in Information Technology, Abu Dhabi, 2011, pp. 179-184.

[7] J. A. Fails, A. Druin, M. L. Guha, G. Chipman, S. Simms, and W. Churaman, "Child's play: a comparison of desktop and physical interactive environments," in Proc. The Conference on Interaction Design and Children, New York, 2005, pp. 48-55.

[8] F. Scharf, T. Winkler, and M. Herczeg, "Tangicons: algorithmic reasoning in a collaborative game for children in kindergarten and first class," in Proc. the 7th International Conference on Interaction Design and Children, New York, 2008, pp. 242-249.

[9] V. Gibsone and M. Douglase, "Criticality: the experience of developing an interactive educational tool based on board games," Journal of Nurse Education Today, vol. 33, pp. 1612-1616, 2013.

[10] T. Bell, H. I. Written, and M. Fellows. "an enrichment and extension programme for primary-aged children," Computer Science Unplugged, 2005.

[11] Y. Rogers, M. Scaife, E. Harris, T. Phelps, S. Price, H. Smith et al., "Things aren't what they seem to be: innovation through technology inspiration," in Proc. the 4th Conference on Designing Interactive Systems:Processes, Practices, Methods, and Techniques, New York, 2002, pp. 373-378.

[12] W. Sluis, I. Weevers et al., "Read-It: five-to-seven-year-old children learn to read in a tabletop environment," in Proc. the 2004 Conference on Interaction Design and Children: Building A Community, 2004, pp. 73-80.

[13] M. Horn and R. J. K. Jacob. "Tangible programming in the classroom with tern," in Proc. the 7th Extended On Human Factors in Computing Systems, New York, 2007, pp. 1965-1970.

[14] A. Sipitakiat and N. Nusen. "Robo-blocks: designing debugging abilities in a tangible programming system for early primary school children," in Proc. the 11th International Conference on Interaction Design and Children, 2012, pp. 98-105.

[15] P. Frei, V. Su, B. Mikhak, and H. Ishii. "Curlybot: designing a new class of computational toys," in Proc. the SIGCHI Conference on Human Factors in Computing Systems, 2000, pp. 129-136.

[16] T. S. McNerney, Tangible Programming Bricks: an Approach to Making Programming Accessible to Everyone, Massachusetts Institute of Technology, 2000.

[17] R. Ibrahim, R. C. M. Yusoff, H. M. Omar, and A. Jaafar, "Students perceptions of using educational games to learn introductory programming," Journal of Computer and Information Science, vol. 4, pp. 205-216, 2011

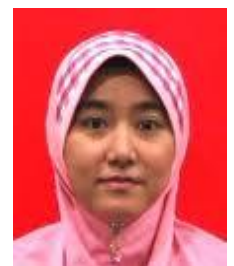

Rashidah Mokhtar was born on 13 June 1980 at Johor State. She obtained her bachelor $(\mathrm{H})$ in science computer in 2002 from Universiti Teknologi Malaysia (UTM). Then she further her master degree in information techology (management) in 2006 also from UTM.

She is now working as a lecturer at Universiti Teknologi MARA, Johor since 2006 until now. Her previous research more on computer and education focus in blended learning and introductory programming. Her interest and publications more on the information system related to quality management system. She also has published a book entitled " 50 Common Mistakes in C++ Programming".

Mrs. Rashidah also has won several awards such as Gold Medal in Invention, Innovation and Design Competition in 2010, 2012 and 2013 for different products.

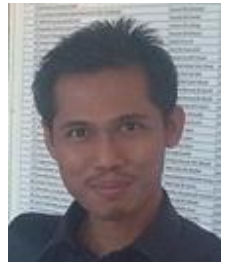

Mohd Lezam Lehat was born on 17 June 1979 at Johor State. He obtained his bachelor in science (computer) in 2001 from Universiti Teknologi Malaysia (UTM). Then, further his master degree in information techology (management) in 2006 also from UTM.

$\mathrm{He}$ is now working as a lecturer at Universiti Teknologi MARA, Johor since 2009 until now.

His previous research related to the knowledge management and he involved in many system and multimedia development product for preschool students.

Mr. Mohd lezam also active in innovation and won several awards such as Invention, Innovation and Design Competition for his product MyAIMS cGloss, CinTa Design and others.

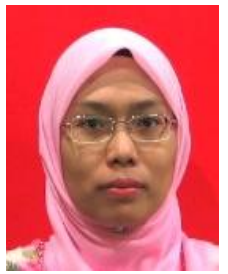

Nora Mohd Basir was born on 4 November 1981 at Johor State. She obtained her bachelor $(\mathrm{H})$ in science (statistics) in 2003 from Universiti Teknologi MARA (UiTM). Then, she furthers her master degree in applied statistics in 2008 from Universiti Malaya (UM)

She is now working as a lecturer at Universiti Teknologi MARA, Johor since 2008 until now. Her previous research more on education focus in improving the knowledge management. Her interests and publications more on the applied statistics that go inter-disciplined with the others field.

Mrs. Nora also has won awards in Invention, Innovation and Design Competition in 2009 for her products.

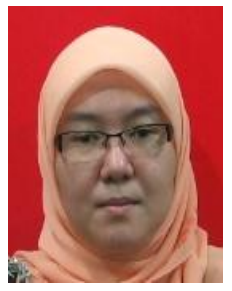

Yusnita Sokman was born on 22 March 1976 at Johor State. She obtained her bachelor $(\mathrm{H})$ in science (computer) in 1999 from Universiti Teknologi Malaysia (UTM). Then, she further her master degree in information technology in 2006 from Universiti Teknologi MARA (UiTM)

She is now working as a lecturer at Universiti Teknologi MARA, Johor since 2000 until now. Her previous research more on human computer interactions and open source software in education.

Mrs. Yusnita also has won several awards in Invention, Innovation and Design Competition in 2009, 2010 and 2012 for different products. 